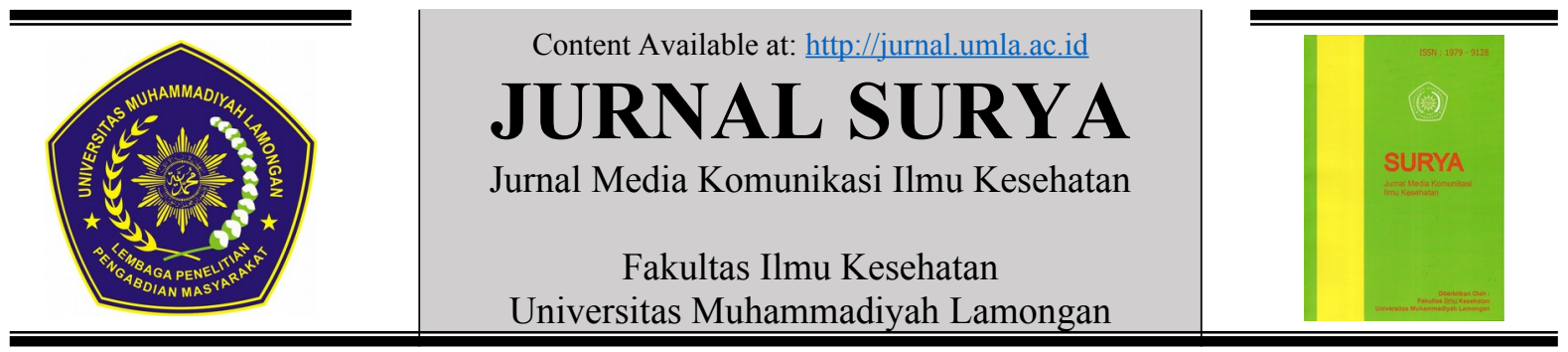

\title{
Hubungan Dukungan Suami dengan Pemilihan Alat Kontrasepsi MKJP atau Non MKJP pada Ibu di Puskesmas Modopuro Kabupaten Mojosari
}

Heni Purwati ${ }^{2}$,Etik Khusniyati ${ }^{2}$

${ }^{1,2}$ Dosen STIKes Bina Sehat PPNI Mojokerto

\section{ARTIKEL INFO}

\section{Article History:}

SM at 09-12-2019

$R V$ at $10-12-2019$

$P B$ at 24-12-2019

\section{Kata Kunci:}

Dukungan Suami

Pemilihan Alat Kontrasepsi

Akseptor KB

\section{Korespondensi Penulis:} etik.khusnivati@gmail.com 08563676868

\section{ABSTRAK}

Background: Kontrasepsi merupakan upaya untuk mencegah terjadinya kehamilan dapat bersifat sementara maupun permanen, masalah yang terjadi pada saat pemilihan alat kontrasepsi pada ibu ialah dukungan suami, dimana seberapa peduli suami dalam mendukung pemilihan alat kontrasepsi.

Objectives: Tujuan penelitian ini adalah untuk mengetahui hubungan dukungan suami dengan pemilihan alat kontrasepsi MKJP atau non-MKJP pada ibu di puskesmas Modopuro kecamatan Mojosari.

Design: Desain yang digunakan adalah analitik korelasi dengan menggunakan pendekatan cross sectional, dengan populasi yaitu akseptor KB di puskesmas Modopuro kecamatan Mojosari khususnya didesa Modopuro sejumlah 1.203 akseptor KB. Sampel penelitian ini diambil dari data menggunakan teknik cluster dengan tipe random sampling sebanyak 120 responden, Data diperoleh dari data kuesioner.

Results: Hasil penelitian selanjutnya di analisa menggunakan uji statistik Chi Square dengan bantuan SPSS V.16 menunjukkan hasil $\rho=0.000>\alpha=0.05$ yang artinya ada hubungan dukungan suami dengan pemilihan alat kontrasepsi MKJP atau non-MKJP pada ibu.

Conclusions: Seorang wanita mengalami perubahan dalam dirinya setelah mempunyai anak, sehingga perlu beradaptasi dengan keadaan baru, disini dibutuhkan dukungan suami dalam memberikan motivasi, pengambilan keputusan, penyediaan sarana dan prasarana kesehatan, sehingga dengan adanya dukungan suami, ibu dapat memilih alat kontrasepsi sesuai dengan keinginan dari kedua belah pihak yang sudah disepakati bersama. 
PENDAHULUAN

Kontrasepsi merupakan upaya untuk mencegah terjadinya kehamilan dapat bersifat sementara maupun permanen (Prawirohardjo,2007). Ada dua metode yaitu MKJP (IUD, implant, MOW dan MOP) dan Non-MKJP (pil, suntik dan kondom) (Departemen Kesehatan RI, 2008). Dalam penggunaan alat kontrasepsi, ada beberapa faktor yang mempengaruhi dalam pemilihan salah satunya faktor eksternal yang berupa dukungan suami (Pendit, 2007). Dukungan suami merupakan salah satu faktor penguat (reinforcing factor) yang dapat mempengaruhi seseorang dalam berperilaku misal dalam pemilihan alat kontrasepsi. Aspek-aspek dukungan dari keluarga (suami) ada empat aspek yaitu dukungan emosional, informasi, instrumental dan penghargaan (Friedman, 1998; Setiadi, 2008).

Hasil Susenas 2015 yang berjudul Analisis Data Kependudukan dan KB didapat bahwa sebagian besar PUS (Pasangan Usia Subur) peserta KB di Indonesia masih mengandalkan kontrasepsi suntikan $(59,57 \%)$ dan pil $(20,71 \%)$ dari total pengguna KB. Sedangkan persentase pengguna Metode Kontrasepsi Jangka Panjang (MKJP) terbesar adalah pengguna IUD (7,30\%) dan Susuk KB (6,21\%). Adapun peserta KB pria yang ada hanya mencapai sekitar $1,27 \%$ (MOP $=0,27 \%$ dan Kondom $=1 \%$ ) total pemakai MKJP adalah $17,01 \%$. Saat ini diperkirakan sekitar 214 juta wanita memiliki kebutuhan yang tidak terpenuhi untuk kontrasepsi modern (WHO,2017). Menurut Dinkes Jatim proporsi peserta KB aktif menurut jenis kontrasepsi di kabupaten Mojokerto pada tahun 2015 didapat pengunaan $\mathrm{KB}$ suntik 109.241, IUD 11.790, MOP 298, MOW 10,572, Implan10.267, Kondom 1.217, Pil 23.015. Berdasarkan data dari Dinkes Mojokerto pada tahun 2016 jumlah peserta KB baru di puskesmas Modopuro, KB MKJP sebanyak 92 sedangkan KB Non-MKJP 375. Layanan keluarga berencana seyogianya dipandang sebagai layanan kesehatan reproduktif bagi wanita dalan konteks yang lebih luas. Seluruh tujuan setiap program yang menangani masalah kesehatan reproduktif wanita harus dapat memberikan kontribusi bagi peningkatan kesehatan dan kesejahteraan wanita (Pendit, 2007). Partisipasi pria secara tidak langsung salah satunya dengan cara mendukung istri dalam ber-KB. Apabila disepakati istri yang akan ber-KB maka peranan suami adalah memberikan dukungan dan kebebasan kepada istri untuk menggunakan kontrasepsi atau cara/metode KB yang akan digunakan (Hermawan, 2012).

Hartanto (2004) dalam Khairunnisa (2014) mengatakan bahwa faktor dukungan suami memegang peranan penting karena suami merupakan kepala rumah tangga dan pengambilan keputusan dalam rumah tangga dilakukan oleh suami termasuk pengambilan keputusan untuk jenis alat kontrasepsi yang digunakan. Hubungan seorang wanita dengan pasangannya juga dapat menjadi faktor dalam menentukan pemilihan kontrasepsi tertentu.

Karena pada banyak masyarakat, pasangan tidak saling berkomunikasi mengenai keluarga berencana, pihak wanitalah yang sering harus memperoleh dan menggunakan alat kontrasepsi bila ingin mengontrol kesuburannya (Pendit, 2007). Jika hanya sasaran para wanita saja yang selalu diberi informasi, sementara para suami kurang pembinaan dan pendekatan, suami kadang melarang istrinya karena faktor ketidaktahuan dan tidak ada komunikasi untuk saling memberikan pengetahuan. Hartanto (2003) dalam Fitri (2012) mengatakan bahwa seorang wanita apabila menggunakan kontrasepsi tidak akan dipakai apabila tidak ada kerja sama dengan suami, hal tersebut merupakan metode kesadaran akan fertilitas yang sangat membutuhkan kerja sama dan saling percaya antara suami istri. Karena itu dengan pemilihan alat kontrasepsi yang akan digunakan perlu dukungan dari suami yang positif agar istri termotivasi untuk memakai alat kontrasepsi serta menuju hubungan yang harmonis antara suami dan istri. Maka perlu dilakukan penelitian tentang bagaimana hubungan dukungan suami dengan pemilihan alat kontrasepsi pada ibu. Seperti para bidan desa memberikan penyuluhan tentang pentingnya menggunakan alat kontrasepsi serta bagaimana dukungan suami untuk pemilihan alat kontrasepsi sangat berpengaruh, semisal saat tidak ada dukungan suami saat ibu ingin berdiskusi tentang alat kontrasepsi mana yang akan dipakai. 


\section{METODE}

Populasi dalam penelitian ini adalah semua Akseptor KB (Keluarga Berencana) di puskesmas Modopuro Kecamatan Mojosari Kabupaten Mojokerto khususnya di desa Modopuro sejumlah 1.203 jiwa. Pengambilan sampling dalam penelitian ini menggunakan teknik Cluster Random Sampling. Analisis data yang digunakan adalah Uji Chi Square.

\section{HASIL PENELITIAN}

\section{Data Umum}

Tabel 1 Distribusi Frekuensi Responden Berdasarkan Usia Ibu

\begin{tabular}{ccc}
\hline Usia Ibu & F & \% \\
\hline 21-25 tahun & 27 & 22.5 \\
26-30 tahun & 75 & 62.5 \\
31-35 tahun & 14 & 11.7 \\
>36 tahun & 4 & 3.3 \\
\hline Jumlah & $\mathbf{1 2 0}$ & $\mathbf{1 0 0}$ \\
\hline Tabel 1 menunjukkan bahwa \\
sebagian besar dari responden usia ibu \\
berusia 26-30 tahun sebanyak 75 responden \\
(62.5\%)
\end{tabular}

Tabel 2 Distribusi Frekuensi Responden Berdasarkan Pendidikan

\begin{tabular}{llcc}
\hline No & Pendidikan Ibu & F & \% \\
\hline 1 & SMP & 29 & 24.2 \\
2 & SMA & 85 & 70.8 \\
3 & Perguruan Tinggi & 6 & 5.0 \\
\hline Jumlah & 120 & $\mathbf{1 0 0}$ \\
\hline \multicolumn{5}{c}{ Tabel } & 2 & menunjukkan & bahwa
\end{tabular}
sebagian besar pendidikan terakhir Ibu tingkat menengah (SMA Sederajat) sebanyak 85 orang $(70.8 \%)$. Dan sebagian kecil adalah SMP sebanyak 29 orang (24.2\%).

Tabel 3 Distribusi Frekuensi Pekerjaan

\begin{tabular}{|c|c|c|}
\hline Pekerjaan Ibu & $\mathbf{F}$ & $\%$ \\
\hline Ibu rumah tangga & a 11 & 92.5 \\
\hline Pegawai Swasta & 7 & 5.8 \\
\hline Wiraswasta & 2 & 1.7 \\
\hline Jumlah & 120 & 100 \\
\hline \multicolumn{3}{|c|}{$\begin{array}{l}\text { Tabel } 3 \text { menunjukkan berdasarkan } \\
\text { bahwa hampir semua responden sebagai Ibu } \\
\text { rumah tangga sebanyak } 111 \text { responden } \\
(92.5 \%) .\end{array}$} \\
\hline
\end{tabular}

Tabel 4 Distribusi Frekuensi Responden Berdasarkan Jumlah Anak

\begin{tabular}{|c|c|c|}
\hline Jumlah anak & $\mathbf{F}$ & $\%$ \\
\hline Belum punya anak & 1 & 0.8 \\
\hline 1-2 anak & 111 & 92.5 \\
\hline 3-4 anak & 8 & 6.7 \\
\hline Jumlah & 120 & 100 \\
\hline
\end{tabular}

Tabel 5 Distribusi Frekuensi Responden Berdasarkan Usia Pernikahan

\begin{tabular}{ccc}
\hline Usia Pernikahan & $\mathbf{F}$ & $\mathbf{\%}$ \\
\hline$<1$ tahun & 0 & 0 \\
1 tahun & 1 & 0.8 \\
$>1$ tahun & 119 & 99.2 \\
\hline Jumlah & $\mathbf{1 2 0}$ & $\mathbf{1 0 0}$ \\
\hline
\end{tabular}

Tabel 5 menunjukkan bahwa seluruh usia pernikahan responden adalah $>1$ tahun sebanyak 119 (99.2\%).

Tabel 6 Distribusi Frekuensi Responden Berdasarkan Riwayat Persalinan Ibu

\begin{tabular}{lcc}
\hline \multicolumn{4}{c}{ Riwayat Persalinah } \\
\hline Operasi & 0 \\
Normal & 120 & 100 \\
\hline Jumlah & $\mathbf{1 2 0}$ & $\mathbf{1 0 0}$ \\
\hline \multicolumn{3}{c}{ Tabel 6 menunjukkan bahwa } \\
seluruh riwayat persalinan ibu normal \\
sebanyak 120 (100\%).
\end{tabular}

\section{Data Khusus}

Tabel 7 Distribusi Frekuensi Responden Berdasarkan Dukungan Suami

\begin{tabular}{|c|c|c|}
\hline \multicolumn{2}{|c|}{ Dukungan Suami F } & $\%$ \\
\hline Mendukung & 77 & 64.2 \\
\hline \multicolumn{2}{|c|}{ Kurang mendukun\&3 } & 35.8 \\
\hline Jumlah & 120 & 100 \\
\hline \multicolumn{3}{|c|}{$\begin{array}{l}\text { sebagian besar peran Dukungan dari suami } \\
\text { dalam kategori mendukung sebanyak } 77 \\
\text { responden }(64.2 \%) \text {. }\end{array}$} \\
\hline \multicolumn{3}{|l|}{$\begin{array}{l}\text { Tabel } 8 \text { Distribusi } \\
\text { berdasarkan } \\
\text { kontrasepsi }\end{array}$} \\
\hline \multicolumn{3}{|c|}{ Pemilihan Kontrasepsi } \\
\hline Non MKJP & 108 & 90.0 \\
\hline MKJP & 12 & 10.0 \\
\hline Jumlah & 120 & 100 \\
\hline
\end{tabular}


Tabel 8 menunjukkan bahwa sebagian besar responden memilih alat kontrasepsi Non MKJP sebanyak 108 responden $(90.0 \%)$.

Tabel 9 Tabulasi Silang Hubungan Dukungan Suami dengan Pemilihan Alat Kontrasepsi Non MKJP atau MKJP Pada Ibu Di Puskesmas Modopuro Kecamatan Mojosari

\begin{tabular}{llllllll}
\hline \multirow{2}{*}{$\begin{array}{l}\text { Do } \\
\text { Suami }\end{array}$} & \multicolumn{4}{c}{ Pemilihan Alat } & \multirow{2}{*}{ Kontrasepsi } & \multirow{2}{*}{ Total } \\
\cline { 3 - 6 } & & Non MKJP & MKJP & \\
\hline & & F & F & \% & F & \% \\
\hline 1 & Mendukung & 72 & 60.0 & 5 & 4.2 & 77 & 64.2 \\
2 & Kurang & 36 & 30.0 & 7 & 5.8 & 43 & 35.8 \\
& Mendukung & & & & & & \\
\hline & Jumlah & $\mathbf{1 0 8}$ & $\mathbf{9 0 . 0}$ & $\mathbf{1 2}$ & $\mathbf{1 0 . 0}$ & $\mathbf{1 2 0}$ & $\mathbf{1 0 0}$ \\
\hline
\end{tabular}

Tabel 9 didapatkan bahwa dari 120 responden yang mempunyai Dukungan suami mendukung 77 responden (64.2\%) dengan 72 responden $(60.0 \%)$ memilih alat kontrasepsi Non MKJP dan 5 responden yang memilih alat kontrasepsi MKJP. Sedangkan 43 responden mempunyai dukungan suami yang kurang sebanyak 43 responden (35.8\%) memilih alat kontrasepsi Non MKJP 36 responden $(30.0 \%)$ dan 7 responden $(5.8 \%)$ memilih alat kontrasepsi MKJP.

Berdasarkan hasil uji statistik Chi Square menggunakan program SPSS didapatkan $\rho=0.000>\alpha=0.05$ sehinga dapat disimpulkan bahwa ada hubungan antara dukungan suami dengan pemilihan alat kontrasepsi Non MKJP atau MKJP pada Ibu.

\section{PEMBAHASAN}

\section{Dukungan suami Dalam Memilih Alat Kontrasepsi Di Puskesmas Modopuro Kec. Mojosari}

Sebagian besar responden mendapat dukungan dari suami sebanyak 77 responden (64.2\%). Sedangkan 43 responden ( 35.8\%) mendapat dukungan yang kurang dari suami.

Dukungan suami adalah dukungan yang diberikan suami terhadap istri, suatu bentuk dukungan di mana suami dapat memberikan bantuan secara psikologis baik berupa motivasi, perhatian dan penerimaan (Goldberger \& Brezbis, 1982 dikutip oleh jurnal Hasanah 2014). Menurut Cohen dan Syme (1984) dari jurnal Hasanah (2014)
Pemberian dukungan sosial dari suami atau istri lebih memiliki keterdekatana yang lebih tinggi dari pada sumber dukungan yang lainnya. Keterdekatan yang dimaksud di sini lebih menekankan pada kualitas hubungan bukan kuantitasnya. Individu yang memiliki suatu hubungan dekat dapat dipercaya cenderung memiliki kesehatan mental yang baik. Dukungan yang diberikan oleh suami pada responden mendukung pemilihan namun ada pula suami yang belum mengerti bagaimana memilih alat kontrasepsi berdasarkan hasil kuesioner pada dukungan instrumental bahwa suami tidak pernah ikut saat penyuluhan kontrasepsi, sehingga dukungan yang diberikan hanya sebatas yang mereka bisa. Dukungan suami yang dihasilkan dalam penelitian ini adalah mendukung pemilihan alat kontrasepsi, yang didapatkan hasil 77 dari total responden 120 . Sedangkan dukungan suami yang kurang didapat 43 responden karena saat penelitian suami banyak yang kurang mengerti tentang alat kontrasepsi MKJP maupun Non-MKJP karena banyak dari suami menyerahkan seluruhnya pemilihan pada istri.

Dari usia ibu sebagian besar responden berusia 26-30 tahun sebanyak 75 responden $(62.5 \%)$. Usia, dimana seorang wanita dapat memengaruhi kecocokan dan akseptabilitas metode-metode kontrasepsi tertentu (Pendit, 2007). Pada umumnya, semakin tinggi pendidikan seseorang semakin baik pula pengetahuannya, bertambahnya umur seseorang dapat pula berpengaruh pada pertambahan pengetahuan yang diperoleh (Wijayanti, 2009; Khairunnisa, 2014). Dari segi usia responden merupakan usia yang pas, bila remaja yang sudah menikah yang mungkin mengalami kesulitan mematuhi syarat-syarat pemakaian metode, misalnya minum pil setiap hari. Menurut keterangan yang didapat saat penelitian pada umur sekitar 26-30 tahun istri banyak membutuhkan sebuah dukungan dari suaminya dalam segala hal.

Pada usia pernikahan didapatkan hampir seluruhnya 119 responden (99.2\%) sudah menikah >1tahun. Selama awal pernikahan pada tahun pertama dan kedua perkawinan pasangan suami istri terkadang harus melakukan penyesuaian satu sama lain. Pada masa penyesuaian ini terkadang suami ataupun istri sering mengalami suatu 
permasalahan yang terkadang dapat menimbulkan ketegangan emosional (Hurlock, 1994; Wardhani, 2012). Berdasarkan penelitian hampir seluruh responden yang peneliti teliti sudah menikah lebih dari 1 tahun yang artinya suami istri sudah saling memahami satu sama lain, dari penelitian yang didapat responden mengatakan bila sewaktu ingin memilih $\mathrm{KB}$ MKJP ataupun Non-MKJP selalu berdiskusi karna komunikasi harus selalu terjaga agar hubungan berjalan dengan baik.

\section{Pemilihan alat kontrasepsi MKJP atau Non MKJP pada ibu Di Puskesmas Modopuro Kec. Mojosari}

Sebagian besar responden memilih alat kontrasepsi Non MKJP sebanyak 108 responden (90.0\%). Pemilihan alat kontrasepsi responden dalam penelitian ini adalah Non MKJP, dimana pemilihan alat kontrasepsi dipengaruhi oleh banyak faktor, salah satunya adalah faktor pribadi, faktor yang muncul dari diri sendiri yaitu paritas/jumlah anak, pendidikan, riwayat persalinan dan hubungan dengan suami (Pendit,2007). Responden kebanyakan memilih alat kontrasepsi jangka pendek atau Non-MKJP menurut responden yang cocok bagi mereka yaitu alat kontrasepsi jangka pendek baik suntik ataupun pil. Dari segi jumlah anak saat ini sebagian besar responden memiliki 1-2 anak sebanyak 111 orang $(92.5 \%)$ sedangkan dari segi riwayat persalinan sebanyak 120 responden (100\%) persalinan normal. Paritas seorang wanita dapat memengaruhi cocok tidaknya suatu metode secara medis. AKDR (Alat Kontrasepsi Dalam Rahim) tidak dianjurkan bagi wanita nulipara karena pemasangan yang lebih sulit, angka ekspulsi yang lebih tinggi daripada wanita yang pernah melahirkan, dan kemungkinan pemakaian AKDR dapat menganggu kesuburan di masa depan (Pendit, 2007). Pemilihan alat kontrasepsi penting untuk dilakukan karena menyesuaikan dengan kondisi dan kebutuhan ibu setelah melahirkan (Khairunnisa, 2014). Sebagian besar responden memiliki anak 1-2 anak, dan semua responden riwayat melahirkan secara normal yang mana setelah melahirkan menentukan alat kontrasepsi yang akan dipilih responden nanti. Yang mana pemerintah mewajibkan 2 anak cukup. Dapat dipastikan bahwa sebagian besar responden berfikir 2 anak sudah cukup.

Pada faktor pendidikan ibu, 85 responden (70.8\%) pendidikan terakhir SMA. Pendidikan bukan semata-mata sebagai sarana untuk persiapan kehidupan yang akan datang tetapi untuk kehidupan anak sekarang maupun yang sedang mengalami perkembangan menuju ke tingkat kedewasaannya (Munib, 2012). Berdasarkan penelitian serta teori bahwa semakin tinggi tingkat pendidikan responden maka semakin mudah responden menerima informasi - informasi kesehatan baik saat penyuluhan maupun dari pihak pihak kesehatan lainnya misal bidan desa. Disini sebagian besar responden tamatan SMA dimana SMA merupakan pendidikan yang mempersiapkan peserta didik menjadi anggota masyarakat yang memiliki kemampuan mengadakan hubungan timbal balik dengan lingkungan sosial budaya dan alam sekitar serta dapat mengembangkan kemampuan lebih lanjut dalam mempersiapkan terjun ke dunia kerja atau pendidikan tinggi.

\section{Hubungan Antara Dukungan Suami dengan Pemilihan Alat Kontrasepsi Non MKJP atau MKJP}

Berdasarkan tabel 9 didapatkan bahwa dari 120 responden yang mempunyai Dukungan suami mendukung 77 responden (64.2\%) dengan 72 responden $(60.0 \%)$ memilih alat kontrasepsi Non MKJP dan 5 responden yang memilih alat kontrasepsi MKJP. Sedangkan 43 responden mempunyai dukungan suami yang kurang sebanyak 43 responden $(35.8 \%)$ memilih alat kontrasepsi Non MKJP 36 responden $(30.0 \%)$ dan 7 responden $(5.8 \%)$ memilih alat kontrasepsi MKJP. Berdasarkan hasil uji statistik Chi Square menggunakan program SPSS didapatkan $\rho=0.000>\alpha=0.05$ sehinga dapat disimpulkan bahwa ada hubungan antara dukungan suami dengan pemilihan alat kontrasepsi Non MKJP atau MKJP pada Ibu. Faktor-faktor yang mempengaruhi pemilihan alat kontrasepsi salah satunya adalah faktor pribadi, faktor yang muncul dari diri sendiri yaitu usia, paritas, dan hubungan dengan suami (Pendit, 2007). Dukungan suami merupakan salah satu faktor penguat (reinforcing factor) yang dapat mempengaruhi seseorang dalam berperilaku 
misal dalam pemilihan alat kontrasepsi (Setiadi, 2008). Seorang wanita mengalami perubahan dalam dirinya setelah mempunyai anak, sehingga perlu beradaptasi dengan keadaan baru, disini dibutuhkan dukungan suami dalam memberikan motivasi, pengambilan keputusan, penyediaan sarana dan prasarana kesehatan, sehingga dengan adanya dukungan suami, ibu dapat memilih alat kontrasepsi sesuai dengan keinginan dari kedua belah pihak yang sudah disepakati bersama. Dari hasil yang didapat peneliti hubungan dukungan suami sangat diperlukan bagi seorang istri untuk memilih alat kontrasepsi yang mana seorang istri selalu mengikuti seorang suami sebagai seorang kepala rumah tangga, adanya kesepakatan antara keduanya mengenai kontrasepsi yang dipakai oleh istri menyebabkan pemakaian alat kontrasepsi dapat berlangsung secara terus menerus yang merupakan usaha penurunan tingkat fertilitas. Menurut istri bahwa alasan suami untuk memberikan dukungan adalah agar istri tidak cepat punya anak lagi atau dapat menjarangkan kehamilan. Karena jika punya banyak anak sulit untuk dipenuhi kebutuhannya apalagi kondisi ekonomi keluarga sangat rendah. Responden yang tidak mendapatkan dukungan dari suami menggunakan alat kontrasepsi dikarenakan suami lebih menginginkan jumlah anak yang banyak dengan anak banyak maka dapat membantu orang tua dalam mencari uang selain itu masih adanya pemahaman banyak anak banyak rezeki. Sedangkan responden yang mendapatkan dukungan dari suami dalam menggunakan alat kontrasepsi dikarenakan antara suami dan istri lebih menginginkan suatu keluarga yang ideal (2 anak) dan apabila mempunyai anak banyak, maka nantinya akan susah untuk membiayai kebutuhan anak disetiap tahap perkembangannya serta tidak sesuai dengan tingkat pendapatan atau penghasilan orang tua. Pada penelitian juga didapat bahwa sebelumnya responden pernah berganti alat kontrasepsi karena tidak cocok dengan alat kontrasepsi itu kemudian responden berganti alat kontrasepsi.

\section{PENUTUP}

\section{Kesimpulan}

Terdapat hubungan dukungan suami dengan pemilihan alat kontrasepsi Non MKJP atau MKJP di Puskesmas Modopuro Kec. Mojosari hal ini karena dengan semakin baik dukungan suami yang diberikan pada ibu, maka semakin berpengaruh terhadap perasaan ibu dan sebagai faktor penguat mempengaruhi ibu berperilaku misal dalam pemilihan alat kontrasepsi Non MKJP atau MKJP karena responden membutuhkan dukungan dari seorang suami/respon dalam pemilihan alat kontrasepsi MKJP maupun Non-MKJP.

\section{Saran}

Bagi peneliti selanjutnya untuk menganalisa faktor yang lain, yang dapat yang dapat di jadikan faktor memilihnya alat kontrasepsi.

\section{DAFTAR PUSTAKA}

Fitri, Rahmi. 2012. Hubungan Faktor Predisposisi, Faktor Pemungkin Dan Faktor Penguat Dengan Pemilihan Kontrasepsi IUD di Wilayah Kerja Puskesmas Pagaran Tapah Darussalam Kabupaten Rokan Hulu Propinsi Riau. Universitas Indonesia: Skripsi.

Hasanah N U. 2014. Hubungan antara dukungan social suami dengan kecenderungan baby blues syndrome pada ibu pasca melahirkan. Retrieved from https://etheses.uin-malang.ac.id/ 613/6/09410060\%20Bab\%202.pdf

Hermawan, D. 2007. Posyandu mendesak direvitalisasi. Jurnal keluarga; Informasi KB dan kependudukan.

Khairunnisa L. 2014. Hubungan dukungan suami dengan pemilihan kontrasepsi iud pada akseptor kontrasepsi iud di puskesmas tegalrejo. Retrieved from http://digilib.unisayogya.ac.id/1081/1/ naskah\%20publikasi\%20nisa.pdf

Munib Achmad. 2012. Pengantar Ilmu Pendidikan. Semarang: Universitas Negeri Semarang Press. 
Pendit, B.U. 2007. Ragam Metode Kontrasepsi. Jakarta : EGC.

Prawirohardjo. 2007. Ilmu Kandungan. Jakarta: Yayasan Bina Pustaka Sarwono Prawirohardjo

Setiadi. 2008. Konsep Dan Proses Keperawatan Keluarga. Yogyakarta: Graha Ilmu.

Wardhani N A K. 2012. Self disclosure dan kepuasan perkawinan pada istri di usia awal perkawinan. Retrieved from

https://media.neliti.com/media/public ations/184266-ID-self-disclosure-dankepuasan-perkawinan.pdf

WHO. 2007. Decision-making Tool for Family Planning Clients and Providers: Technical Adaptation Guide. Geneva: Department of Reproduction and Research World Health Organization. 